\title{
RADIOCARBON CHRONOLOGY OF ARCHAEOLOGICAL SITES OF THE KURILE ISLANDS
}

\author{
G. I. ZAITSEVA, S. G. POPOV, A. P. KRYLOV
}

The Institute of the History of Material Culture of the Russian Academy of Sciences Dvorts-ovaya Nabezhnaya 18, St. Petersburg 191065 Russia

\section{YU. V. KNOROZOV and A. B. SPEVAKOVSKIY}

Peter the Great Museum of Anthropology and Ethnography (Kunstkammer), Russian Academy of Sciences, 199034 St. Petersburg, Russia

One of the theories of Paleo-Indian migration from Asia to America (Chard 1963) proposes that the most probable route was along the coast of the Sea of Okhotsk through Japan, Kamchatka and the Aleutian islands. To study the problem of New World population origins, we are attempting to correlate archaeological sites in this region. Our aim is to examine connections of the earliest cultures of the Far East and Siberia with the cultures of Sakhalin, the Kurile Islands, Japan and America.

Until recently, the Kurile Islands were little studied, and were missing from discussions of the Pacific Ocean cultures (Vasilevskiy 1975). Though excavations began at the end of the 19th century, Kozyreva (1967) initiated systematic archaeological research of the islands. More recent studies have provided new information regarding ethnographic and chronological correlations of the Kurile Islands and continental cultures. Steshenko and Gladyshev (1977) and Golubev (1989) recognized Neolithic, Okhotsk and Ainu periods in the region. Despite the great amount of material collected by the beginning of the 1980 s, the chronology of the cultures of the Kurile Islands was little known because of the paucity of ${ }^{14} \mathrm{C}$ dates for the area.

The chronology of site occupation in the Kurile Islands and Sakhalin is based mainly on typological and stratigraphic correlations with cultures of Hokkaido, Japan. Samples for ${ }^{14} \mathrm{C}$ dating were collected from Sakhalin. ${ }^{14} \mathrm{C}$ analysis was conducted in the Novosibirsk (SOAN) and Magaden (MAG) laboratories; results were published by Shubin and Shubina (1984). Based on ${ }^{14} \mathrm{C}$ dates, it appears that occupation of Sakhalin began ca. 5000 BC.

Since 1982, Yu. V. Knorozov and A. B. Spevakovskiy have conducted annual excavations in the Kurile Islands. Figure 1 shows site locations. Charcoal and human and animal bones collected for ${ }^{14} \mathrm{C}$ dating were analyzed by liquid scintillation counting at the laboratory of the Institute of the History of Material Culture (LE) for $30 \mathrm{~min}$. Because the samples were collected in a volcanically active region, they were treated first with standard (acid-base-acid) treatment with $\mathrm{HCl}$ and $\mathrm{NaOH}$, and then with $\mathrm{HCl}-\mathrm{HNO}_{3}(3: 1)$ solution for $30 \mathrm{~min}$.

Most samples were collected from Iturup Island, where many settlements in different parts of the island were investigated. Previously, the earliest date was $4220 \pm 160 \mathrm{BP}$ for the Kasatka settlement (Knorozov et al. 1989; Zaitseva, Markov and Knorozov 1989), but 1988 excavations provided a sample from the Yankito settlement, which dated to $6980 \pm 50 \mathrm{BP}$, the oldest result. Therefore, the Neolithic chronology of the Far East islands needs correction, because Neolithic sites on Sakhalin were once considered the oldest (Vasilevsky 1989). 
Table 1 lists the 45 available ${ }^{14} \mathrm{C}$ dates for the Kurile Islands. These dates indicate that the Neolithic cultures of the Kurile Islands existed $c a .2000 \mathrm{yr}$ earlier than was previously thought. These dates will also allow us to compare cultural chronologies and determine cultural origins and relations. Undoubtedly, further studies of Kurile Islands chronology will enable us to assess our current interpretations.

TABLE $1 .{ }^{14} \mathrm{C}$ Dates from the Kurile Islands

\begin{tabular}{|c|c|c|c|}
\hline Lab no. & Settlement & Location, material & $\begin{array}{l}{ }^{14} \mathrm{C} \text { date } \\
\text { (yr BP) }\end{array}$ \\
\hline \multicolumn{4}{|l|}{ Iturup Island } \\
\hline LE-3230 & Yankito & Cultural layer, charcoal & $6980 \pm 50$ \\
\hline LE-4462 & Kasatka & Hill, cultural layer, charcoal & $4220 \pm 160$ \\
\hline LE-4220 & Olya & Cultural layer, $0.4 \mathrm{~m}$ depth, charcoal & $4020 \pm 30$ \\
\hline LE-4083 & Ribaky & Cultural layer, charcoal & $3980 \pm 60$ \\
\hline LE-2820 & Beriozovka & Sand dune, cultural layer, $0.1 \mathrm{~m}$, chr. & $3610 \pm 40$ \\
\hline LE-2167 & Olya & Cultural layer, $0.3 \mathrm{~m}$ depth, charcoal & $3610 \pm 40$ \\
\hline LE-2374 & Lesozavodsk & Ravine, $0.6 \mathrm{~m}$ depth, charcoal & $3560 \pm 40$ \\
\hline LE-4459 & Tankovoe Lake & Whaleback hill 3, $0.3 \mathrm{~m}$ depth, chr. & $3550 \pm 20$ \\
\hline LE-2373 & Lesozavodsk & Lowest cultural layer, charcoal & $3020 \pm 40$ \\
\hline LE-4458 & Tankovoe Lake & East shore, cultural layer, charcoal & $2990 \pm 110$ \\
\hline LE-2369 & Tankovoe Lake & East shore, last slope, charcoal & $2930 \pm 40$ \\
\hline LE-3231 & Kasatka & Cultural layer, charcoal & $2720 \pm 60$ \\
\hline LE-2372 & Tankovoe Lake & W. shore, lowest cultural layer, chr. & $2710 \pm 40$ \\
\hline LE-2821 & Beriozovka & Hill, $0.5 \mathrm{~m}$ depth, charcoal & $2710 \pm 40$ \\
\hline LE-4460 & Malaya Kuybishevka & Mound, charcoal & $2710 \pm 40$ \\
\hline LE-2621 & Tankovoe Lake & East shore, hill, charcoal & $2520 \pm 40$ \\
\hline LE-3226 & Tankovoe Lake & East shore, charcoal & $2460 \pm 40$ \\
\hline LE-2419a & Olya & Cultural layer, $0.2 \mathrm{~m}$ depth, charcoal & $2410 \pm 40$ \\
\hline LE-4081 & Tankovoe Lake & West shore, hill, charcoal & $2350 \pm 80$ \\
\hline LE-2368 & Tankovoe Lake & East shore, burial, charcoal & $2320 \pm 40$ \\
\hline LE-2371 & Tankovoe Lake & East shore, hill, bones & $2210 \pm 40$ \\
\hline LE-2370 & Tankovoe Lake & Hill, lowest culture layer, charcoal & $2170 \pm 80$ \\
\hline LE-4461 & Malaya Kuybishevka & Fireplace, charcoal & $2110 \pm 80$ \\
\hline LE-3224 & Malaya Kuybishevka & Mound, charcoal & $2050 \pm 50$ \\
\hline LE-2620 & Tankovoe Lake & West shore, camp hearth, charcoal & $2030 \pm 40$ \\
\hline LE-2623 & Malaya Kuybishevka & Mound, charcoal & $1930 \pm 40$ \\
\hline LE-4084 & Reidovo & Pit 1 , charcoal & $1460 \pm 160$ \\
\hline LE-3229 & Pioner II & Cultural layer, charcoal & $1300 \pm 50$ \\
\hline LE-3221 & Tankovoe Lake & Cultural layer, charcoal & $1260 \pm 40$ \\
\hline SOAN-1128 & Reidovo & Pit, $0.9 \mathrm{~m}$ depth, charcoal & $1290 \pm 40$ \\
\hline SOAN-1129 & Kurilsk & Cultural layer, charcoal & $1060 \pm 85$ \\
\hline LE-4080 & Olya & Cultural layer 2 , ravine, charcoal & $1000 \pm 50$ \\
\hline LE-2828 & Beriozovka & West shore, culture layer, charcoal & $940 \pm 40$ \\
\hline LE-4082 & Isis & Cultural layer, charcoal & $790 \pm 70$ \\
\hline LE-2817 & Beriozovka & Hill, cultural layer, charcoal & $510 \pm 40$ \\
\hline
\end{tabular}


TABLE 1. (Continued)

\begin{tabular}{lllc} 
Lab no. & Settlement & Location, material & $\begin{array}{c}{ }^{14} \mathrm{C} \text { date } \\
(\mathrm{yr} \mathrm{BP})\end{array}$ \\
\hline $\begin{array}{l}\text { Shikotan Island } \\
\text { LE-4029a }\end{array}$ & Animal bones & \\
LE-4029b & Human bones & $2510 \pm 20$ \\
LE-4547 & Excavation, charcoal & $2280 \pm 20$ \\
LE-4546 & Shell hill, charcoal & $1980 \pm 130$ \\
LE-4542 & Excavation, charcoal & $1910 \pm 110$ \\
LE-3011 & Shell hill, charcoal & $1750 \pm 110$ \\
Kunashir Island & Flekhino & Fireplace, charcoal & $930 \pm 40$ \\
LE-2367 & Alekhino & Hollow, charcoal & $2460 \pm 40$ \\
LE-2622 & Furukamatu & Hill 1, charcoal & $1790 \pm 40$ \\
LE-2824 & & $800 \pm 40$ \\
Paramushir Island & Savushkino & Charcoal & \\
LE-4087 & & & $1160 \pm 80$ \\
\hline
\end{tabular}

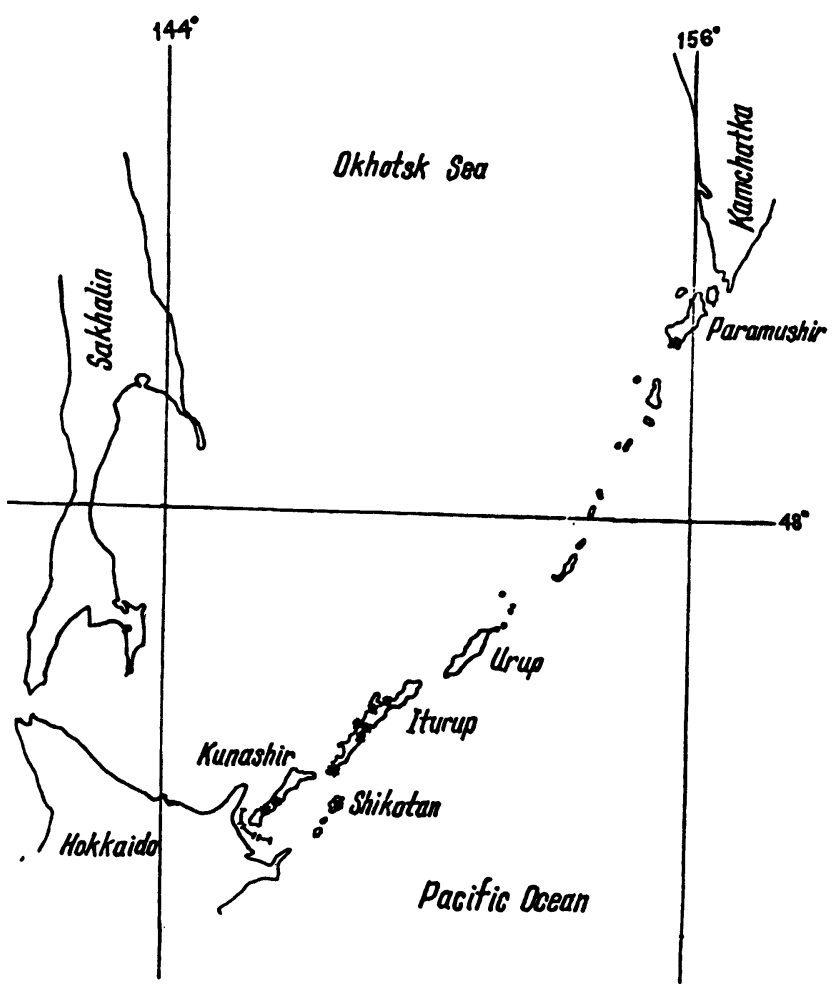

Fig. 1. Archaeological sites of the Kurile Islands 


\section{REFERENCES}

Chard, C. S. 1963 The Old World roots: Review and speculation. Anthropological Papers of the University of Alaska 10(2): 115-121.

Golubev, V. A. 1989 Archaeological monuments of the Kurile Islands. In Problems in Soviet Far East History. Vladivostok: 7-9.

Knorozov, Yu. V., Zaitseva, G. I., Popov, S. G. and Krylov, A. P. 1989 Radiocarbon chronology of the ancient settlements of Iturup Island. In Thesis of Reports from the All-Union Conference "Quaternary Period Chronology". Moscow: 102-103.

Kozyreva, R. V. 1967 Ancient Sakhalin. Leningrad, Nauka.

Steshenko, T. V. and Gladyshev, S. A. 1977 The ancient monuments of the Kurile Islands. In Archaeological Investigations in the Sakhalin Region. Vladivostok: 21-38.

Shubin, V. O. 1977 First non-ceramic artifacts from
Sakhalin and Kurile Islands. In Archaeological Investigations in the Sakhalin Region. Vladivostok: 5- 12. Shubin, V. O. and Shubina, O. A. 1984 New Radiocarbon Data in Archaeology of the Sakhalin Region. Yuszno-Sakhalinsk.

Vasilevskiy, A. A. 1989 Absolute dates of the settlements Kuznetsovo 3 and Yusznaya 2 and their interpretation. In Problems of Local Natural History. Ussurijsk: $12-15$.

Vasilevskiy, R. S. 1975 The adaptation of the population of the northern region of the Pacific Ocean to coastal conditions. In Relations Between the Ancient Cultures of Siberia and its Closest Territories. Novosibirsk: $128-142$.

Zaitseva, G. I., Markov, Yu. N. and Knorozov, Yu. 1989 The absolute chronology of settlements in the Iturup and Kunashir Islands. In Problems of Local Natural History. Ussurijsk: 23-24. 